\title{
Formal Logic and Carnap's Rejection of Metaphysics: A Short Reflection
}

\author{
Michael Perrick \\ Retired, Berg en Dal, The Netherlands \\ Email: m.perrick@kpnmail.nl
}

How to cite this paper: Perrick, M. (2018). Formal Logic and Carnap's Rejection of Metaphysics: A Short Reflection. Open Journal of Philosophy, 8, 561-564. https://doi.org/10.4236/ojpp.2018.85040

Received: October 19, 2018

Accepted: November 26, 2018

Published: November 29, 2018

Copyright (C) 2018 by author and Scientific Research Publishing Inc. This work is licensed under the Creative Commons Attribution International License (CC BY 4.0).

http://creativecommons.org/licenses/by/4.0/

\begin{abstract}
From a seemingly impartial, unprejudiced point of view, Carnap claims to be able to eliminate, once and for all, all of metaphysics by "logical analysis". We argue, on the one hand, that as far as Carnap's analysis is strictly logical it leaves metaphysics untouched. On the other hand, we argue that as far as his analysis is epistemological it directly hits metaphysics, but lacks the prerogatives of formal logic, especially formal logic's impartiality.
\end{abstract}

\section{Keywords}

Formal Logic, Applied Logic or Epistemology, Rejection of Metaphysics

\section{Logical Analysis and the Rejection of Metaphysics}

In his famous (Carnap, 1932), Carnap claims that it is only now, thanks to the development of logic during recent decades, that logical analysis reveals the alleged statements of metaphysics to be pseudo-statements. As is evident from (Carnap, 1930-1931), this development concerns primarily formal logic. What is new in Carnap's criticism of metaphysics is that his rejection of metaphysics is claimed to be a matter of logic. ${ }^{1}$ As Philipp Frank put it:

"People who have always had an aversion against metaphysics felt an almost miraculous comfort by having their aversion justified by 'logic'." (Frank, 1963: p 159).

In all his anti-metaphysical writings it is logical analysis that passes judgment on metaphysics and, therefore, we have to find out what exactly Carnap has in mind when he uses this term. The term logical analysis has, as Carnap himself admits, a quite broad meaning, and this has fundamental consequences for his rejection of metaphysics. The terms "logic" and "logical analysis" are taken by

${ }^{1}$ Cf. A.J. Ayer, 1967, 34. 
Carnap, in several places, to include both formal logic and applied logic, or epistemology. For instance, in (Carnap, 1930-1931: p. 133): "Logic is the method of philosophizing. Logic is understood here in the broadest sense. It comprehends pure, formal logic and applied logic or the theory of knowledge."

The fact that logical analysis covers both formal and applied logic, or epistemology, has far reaching consequences for the status of Carnap's criticism of metaphysics. This fact comes to the fore, for instance, in two different kinds of pseudo-sentences, which have their origin in respectively formal logic and epistemology. It may be useful to say a few words about formal logic. To Aristotle and Kant, for instance, formal logic is a discipline that has no subject matter of its own and only takes into consideration the so-called formal aspects of our thinking and knowledge. Quite generally, most philosophers and logicians seem to agree that formal logic, lacking any special subject matter, is characterized by relevance to all science, partiality toward none (Quine, 1970: p. 98), in short, by "topic-neutrality" (Quinton, 1967: p. 123). Since for Carnap formal logic consists of analytical sentences that supposedly do not give any information about extra-logical reality, we may assume that Carnap subscribes to the conception of logic just described.

\section{Formal Logic and Metaphysics}

Suppose that we could prove, by pure, formal logic alone, that metaphysics is impossible. Such a proof would be of eminent importance, for in that case we would have proved, from a strictly impartial, neutral, and unprejudiced point of view, that metaphysics is impossible. This seems to be too good to be true, and so it is. Even if it turned out that all metaphysics suffered from irreparable, strictly logical defects, denounced by our logical analysis, one fundamental aspect necessarily would have been left out of consideration, to wit, that the subject matter and the descriptive terms of the denounced statements are metaphysical. Formal logic abstracts from the meanings of the non-logical, metaphysical terms, precisely because formal logic is characterized by topic-neutrality and impartiality. Formal logic leaves metaphysics as such untouched. Consider, to illustrate this, the following two pseudo-statements:

1) Being is the highest principle of reality and or.

2) Water boils at $100^{\circ} \mathrm{C}$ and or.

According to Carnap, both these statements are in conflict with logical syntax, and this is the only point that counts for formal logic. The fact that the descriptive terms of statement 1. are metaphysical and those of statement 2. empirical does not matter at all.

It seems that, even if we could prove, by pure, formal logic alone, that metaphysics is one big logical morass, this would not bring Carnap one step nearer to his goal, the elimination of metaphysics. Formal logic simply does not and cannot touch on metaphysics as such, because of its formal character and topic-neutrality. If formal logic rejects some metaphysical statements as pseudo-statements, this happens because they are in conflict with logical syntax, 
because they are not "well-formed formulas" (Church), but not because they are metaphysical.

\section{Applied Logic and Metaphysics}

No wonder that Carnap introduces other means to attain his goal, but under the same umbrella term, logical analysis. "Logical analysis" can, of course, just mean the application of formal logic to some subject matter, for instance, metaphysics. In that case, logical analysis is still purely formal. Carnap, however, has something more specific in mind, to wit the application of the empiricist criterion of significance. ${ }^{2}$ This means that logical analysis takes the form of an epistemological inquiry into the question of the meaningfulness of metaphysics.

Whatever the merits of this procedure, some critical remarks are in order. In Carnap's logical positivist epistemology, in which the negation of the synthetic a priori takes center point, metaphysics is directly attacked because metaphysical terms are at odds with the empiricist criterion of significance. Rejection of metaphysics on material grounds, because of its content, is a constant in empiricist epistemology from Hume till logical positivism and Carnap. Carnap's main objection to metaphysics is its claim to give us knowledge about something which is over or beyond all experience (Carnap, 1935: pp. 209-210; 1932: p. 76; 1930-1931: p. 135). To be sure, nothing needs be wrong with such an argument. But the argument is clearly epistemological, and this has far-reaching consequences. Unlike formal logic, epistemology cannot be characterized as topic-neutral and impartial; it considers the material aspects of knowledge claims. Empiricist epistemology, of different sorts, touches directly on metaphysics; it criticizes the endeavors of metaphysicians to attain knowledge of things that are over or beyond possible experience. In respect of these endeavors, one can hardly characterize empiricist epistemology as impartial or unprejudiced, let alone as "tolerant".

\section{Final Remarks}

Under the umbrella term "logical analysis" we find in Carnap's writings two quite divergent kinds of argument against metaphysics. The epistemological argument rests on the empiricist criterion of empirical significance. Sentences at odds with this criterion are called pseudo-statements. If a statement is in conflict with formal logic it is also called a pseudo-statement, but for quite different reasons. In some cases, Carnap adduces both a logical and an epistemological argument against a piece of metaphysics, for instance, in his famous criticism of Heidegger (Carnap, 1932: pp. 69-71). ${ }^{3}$

${ }^{2}$ Originally this was the verification principle. Later, this principle was mitigated by Carnap (and others). I will leave the further developments concerning this principle out of consideration, and simply speak of the empiricist criterion of significance. Nothing further depends on its precise interpretation.

${ }^{3}$ Ironically, of all people Wittgenstein, who played a major part in Carnap's anti-metaphysical stance, expressed his sympathy for Heidegger's point of view in the piece famously criticized by Carnap. Cf. Murray, 1974, 501-504. 
However, the epistemological and the strictly logical argument are not integrated parts of one encompassing argument against metaphysics, and they cannot be. The epistemological argument directly touches on the content of metaphysics, which the logical argument (as formal) necessarily has to leave untouched.

Carnap claims to be able to eliminate metaphysics once and for all by "logical analysis". I have argued that as far as his argument concerns formal logic it leaves metaphysics as such untouched. (The same holds for any other discipline). As for his epistemological argument, if we disregard some technicalities, there is nothing new under the sun, compared with, for instance, Hume's critique of metaphysics. Epistemological arguments, however, lack the impartiality of formal logic.

\section{Conflicts of Interest}

The author declares no conflicts of interest regarding the publication of this paper.

\section{References}

Ayer, A. J. (1967). Language, Truth and Logic (2nd ed.). London: Victor Gollancz LTD.

Ayer, A. J. (Ed.) (1959). Logical Positivism. New York: Free Press.

Carnap, R. (1930-1931). The Old and the New Logic. In A. J. Ayer (Ed.), Logical Positivism (pp. 133-147). Glencoe, IL: The Free Press.

Carnap, R. (1932). The Elimination of Metaphysics through Logical Analysis of Language. In A. J. Ayer (Ed.), Logical Positivism (pp. 60-81). Glencoe, IL: The Free Press.

Carnap, R. (1935). The Rejection of Metaphysics. In M. Weitz (Ed.), 20th-Century Philosophy: The Analytic Tradition (pp. 206-220). New York: Free Press.

Frank, Ph. (1963). The Pragmatic Components in Carnap's 'Elimination of Metaphysics'. In P. A. Schilpp (Ed.), The Philosophy of Rudolf Carnap (pp. 159-165). La Salle, IL: Open Court.

Murray, M. (1974). A Note on Wittgenstein and Heidegger. The Philosophical Review, LXXXIII, 501-504. https://doi.org/10.2307/2183917

Quine, W. V. (1970). Philosophy of Logic. Englewood Cliffs, NJ: Prentice Hall.

Quinton, A. (1967). The a Priori and the Analytic. In P. F. Strawson (Ed.), Philosophical Logic (pp. 107-129). Oxford: Oxford University Press. 